\title{
Factors Affecting on Work Empowerment among Nurses at Main Assuit University Hospital
}

\author{
Reda Hassan Hussein, Kawther Abd El-Motagally Fadel, and Fatma Rushdy Mohamed \\ Demonstrator in Nursing Administration Department, Faculty of Nursing, Assuit University \\ Professor of Public Health \&Community Medicine ,Faculty of Medicine, Assuit University \\ Assistant Professor of Nursing Administration Department, Faculty of Nursing, Assuit University
}

\begin{abstract}
:
Over the past several decades, the traditional superior- subordinate model for management has given way to more democratic approaches. A core concept for most of these new approaches to management is empowerment. 'Empowerment is management practice of sharing information, rewards, and power with employees so that they can take initiative and make decisions to solve problems and improve service and performance. Aim: Is to study factors that promote empowerment among nurses at Main Assiut University Hospital. Subject and method: The research design a comparative descriptive design, study subject consisted of (237) staff nurses working at Main Assiut University Hospital. The data collected through self - administered questionnaire includes demographic data sheet and work empowerment promoting factors scale which developed by Shelton (2002). Results: There is significant difference among different departments regarding empowerment competence, empowerment selfdetermination and interactional justice. There were no statistically significant differences between all factors of empowerment with sex and levels of education among the studied nurses. The study concluded that empowerment meaning, competence, self determination and its' impact will promote nurses empowerment rather than procedural justice and international justice which present as regard to department, age, sex, level of education, years of experience. So, nurse managers must provide staff nurses by sources of job-related empowerment, namely access to opportunities, information, support and resources and nurses should be allowed to participate in decision making to empower them, as well as increasing their feeling of autonomy.
\end{abstract}

Key Words: Factors- Work Empowerment- Nurses.

\section{Introduction:}

Over the past several decades, the traditional superior- subordinate model for management has given way to more democratic approaches. A core concept for most of these new approaches to management is empowerment. The empowerment of employees allows them more control and responsibility over their work (Leiter\& Laschinger, 2006).

In a health care system, nurses are in the frontline of direct patient care. They spend most time with patients and fulfill their needs. Hence, nurses are the face of hospital and the key persons to make significant contributions to healthcare restructure and patient satisfaction. The quality of patient care is directly affected by the degree to which hospital nurses are empowered in participation in decision making regarding their patients' care plan and are central to the organizational decision making (Setoyama, 2000) .

In order to provide better patient care, nurses should be empowered to decide how they practice and what kind of working situation is acceptable for fulfilling their professional responsibilities. People are empowered to reach organizational goals if their work environments are structural in ways that provide access to information, support and resources necessary to getting the job done, as well as opportunities to learn and grow. These organizational structures are important determinants that affect behavior of the individual (Yi Liu, 2008).

Kukkanen, (2003) demonstrated that there are five categories describing factors that affect on empowerment include: - Moral principles, Personal integrity, Expertise, Future orientedness, and Sociability.

While, Hassan (2010) mentioned that the job related empowerment factors includes:

1- Information is defined as knowledge about work goals, plans, organizational decisions, and changes in policies, environmental relationships, and future decisions in an organization;

2-Support is described as the feedback and guidance received from superiors, peers, and subordinates has added that support is backing, acknowledgment of achievements, endorsement, legitimacy, approval, advice, and problem solving of the work environment.

3-Resources: Access to resources refers to the ability to exert influence in the organization to bring in needed materials. Examples of these are equipment, supplies, space, and human resources necessary to do the job; and

Vol (1) , No (1) , June 2013 
4- Opportunities is described as the chances for growth and mobility in the organization. It involves chances to increase knowledge and skills, competencies of individuals, give them recognition and rewards, provide possibilities for their growth and advancement in their positions, and to participate on committees, task forces, and interdepartmental work groups.

The role of managers shifts from control to facilitation and coordination of work processes. There is less focus on decision making and more focus on good communications, education, training, and leadership. Besides, one of the primary roles of managers becomes to help team members develop the confidence and skills to make good decisions and to maximize their full potential (Watson, 2003).

Leaders empower staff by giving them the tools they need to do a good job. For example, a good nursing leader keeps her staff informed about innovations, techniques or educational opportunities. She advises her team about service educational offerings, or she brings in speakers to address specific concerns of the team. She enables her staff to participate in an enriching experience (Kotelnikov, 2001).

\section{Significance of the study}

Empowerment creates and sustains a work environment that speaks to values that facilitate the employee's choice to invest in and own personal action and behaviors resulting in positive contributions to the organization's mission .So, the researcher want to know factors that promoting empowerment among nurses at Assuit University Hospital to achieve hospital mission.

\section{Aim of the study}

The present study aims to:

Study factors that promote empowerment among nurses at Main Assuit University Hospital.

\section{Subject and Method}

\section{Study design}

A comparative descriptive design was utilized to carry out the present study.

\section{Setting}

The present study was conducted at Main Assuit University Hospital.

\section{Subject}

The present study included all nurses who are working at general and special medical and surgical departments at Main Assiut University Hospital with total number $(\mathrm{n}=237)$.

\begin{tabular}{|c|c|}
\hline Departments & Number of staff \\
\hline $\begin{array}{l}\text { General surgical } \\
\text { departments. } \\
\text { - Unit A (A1\&A2). } \\
\text { - Unit B (B1\& B2). } \\
\text { - Unit C (C1\& C2). }\end{array}$ & $\begin{array}{l}22 \\
20 \\
23\end{array}$ \\
\hline $\begin{array}{cl}\text { surgical } & \text { departments. } \\
\text { Special } & \\
\text { - } & \text { Vascular department. } \\
\text { - } & \text { Neurosurgery } \\
& \text { department. } \\
\text { - } & \text { Cardio-Thoracic } \\
& \text { department. } \\
\text { - } & \text { Plastic surgery. } \\
\end{array}$ & $\begin{array}{l}12 \\
9 \\
9 \\
8\end{array}$ \\
\hline $\begin{array}{ll}\text { General } & \text { medical } \\
\text { departments. } \\
\text { - } & \text { Female unit. } \\
\bullet & \text { Male unit. } \\
\text { - } & \text { Blood disease unit. }\end{array}$ & $\begin{array}{l}23 \\
20 \\
12\end{array}$ \\
\hline $\begin{array}{ll}\text { Special } & \text { medical } \\
\text { departments. } \\
\text { - } \\
\text { - } \quad \text { Tropical department. } \\
\text { - Neurology department. } \\
\\
\text { - department. } \\
\text { Dermatology } \\
\text { - department. } \\
\text { Cardiac vascular } \\
\\
\text { dept. } \\
\end{array}$ & $\begin{array}{l}19 \\
20 \\
15 \\
15 \\
10\end{array}$ \\
\hline Total & 237 \\
\hline
\end{tabular}

\section{Data collection tool}

Self- administered questionnaire sheet consisted of two parts.

\subsection{1) Socio demographic characteristics}

It was designed to collect personal data as unit of work, age, sex, qualification, and years of experience.

\subsection{2) Work Empowerment Promoting Factors Scale (WEPS).}

It consists of twenty seven items structured in six empowerment categories : (empowerment meaning (EM) includes (three items) , empowerment competence (EC) includes (three items), self determination (ES) includes (three items), empowerment impact (EI) includes (three items), procedural justice $(\mathrm{P})$ includes (six items), interactional justice(I) includes (nine items). A questionnaire sheet was developed by Shelton (2002).

\subsection{3) Scoring System.}

The scoring system of this questionnaire is a five point likert scale (strongly agree $=5$, agree $=4$, neutral $=3$, disagree $=2$, and strongly disagree $=1$ ) . 


\section{Administrative Design:}

An official permission had been obtained to collect necessary data from hospital director, director of Nursing Administration Department, and head nurse of each selected unit at Main Assiut University Hospital. Oral consent was taken from the participatory nurses in the present study.

\section{Operational Design}

\section{1) Preparatory phase}

This phase took about three months from October to December 2010.In reviewing the available literatures concerning the topic of the study, and translation of the study tools from English to Arabic.

\section{2) Pilot study}

A pilot study was fulfilled to test the questionnaire reliability, feasibility, and applicability. It was carried out on twenty four nurses included in the study sample of the selected department from Main Assiut University Hospital because there was no necessary modifications done for the study tool . Data collected from the pilot study were analyzed. Pilot study has also served in estimating the time needed for filling the questionnaire, and it revealed that each questionnaire would take about 15 minutes for filling. The results of assessment of the reliability of the study tool, by measuring its internal consistency using Cronbach's alpha coefficient method. As the table shows, all the coefficients were high, exceeding 0.80 . The only exception was for empowerment self determination factor, which had $\alpha$ - coefficient $=0.64$. The overall of the total work empowerment factors had an internal consistency of $\alpha=0.95$.

\section{3) Data collection}

The researcher set with each subject in the study explained the purpose of the study and asked for participation. After obtaining verbal consent, the study tool given to the participated nurses to be filled though Self- administered questionnaire .This took about fifteen minutes for each participant to fill the questionnaire. The whole duration for data collection took about three months from January to March 2011.

\section{4.) Statistical Analysis:}

Data entry and statistically analysis were done using SPSS 16.0 Statistical Soft Ware Package. Data were presented using descriptive statistics in the form of frequencies, mean, standard deviation and range. ANOVA and t-test were used for assessment of the inter-relationships among quantitative variables. Statistical significance was considered at P-value $\leq 0.05$.
Table (1): Socio-demographic characteristics of studied nurses at Main Assiut University Hospital, (n=237), 2011.

\begin{tabular}{|c|c|c|}
\hline \multirow{2}{*}{$\begin{array}{l}\text { Socio-demographic } \\
\text { characteristics }\end{array}$} & \multicolumn{2}{|c|}{$(\mathrm{No}=237)$} \\
\hline & No. & $\%$ \\
\hline \multicolumn{3}{|l|}{ Sex: } \\
\hline - Male & 65 & 27.4 \\
\hline - Female & 172 & 72.6 \\
\hline \multicolumn{3}{|l|}{ Age in years: } \\
\hline - $<30$ & 134 & 56.5 \\
\hline - $30-<40$ & 69 & 29.2 \\
\hline - 40 and more & 34 & 14.3 \\
\hline Mean \pm SD & \multicolumn{2}{|c|}{$29.7 \pm 7.9$} \\
\hline \multicolumn{3}{|l|}{ Level of education: } \\
\hline - Diploma & 229 & 96.6 \\
\hline - Technical institute & 8 & 3.4 \\
\hline \multicolumn{3}{|l|}{ Department of work : } \\
\hline $\begin{array}{ll}\begin{array}{l}\text { General } \\
\text { departments }\end{array} & \text { surgical } \\
\end{array}$ & 65 & 27.4 \\
\hline Unit A (A1 \& A2) & 22 & 9.3 \\
\hline Unit B (B1 \& B2) & 20 & 8.4 \\
\hline Unit $\mathrm{C}(\mathrm{C} 1 \& \mathrm{C} 2)$ & 23 & 9.7 \\
\hline $\begin{array}{ll}\begin{array}{l}\text { Special } \\
\text { departments }\end{array} & \text { surgical } \\
\end{array}$ & 38 & 16.0 \\
\hline Vascular & 12 & 5.1 \\
\hline Neurosurgery & 9 & 3.8 \\
\hline Cardio-Thoracic & 9 & 3.8 \\
\hline Plastic surgery & 8 & 3.4 \\
\hline $\begin{array}{l}\text { General medical } \\
\text { departments }\end{array}$ & 55 & 23.2 \\
\hline Female unit & 23 & 9.7 \\
\hline Male unit & 20 & 8.4 \\
\hline Blood disease unit & 12 & 5.1 \\
\hline $\begin{array}{ll}\begin{array}{l}\text { Special } \\
\text { departments }\end{array} & \text { medical }\end{array}$ & 79 & 33.3 \\
\hline Tropical & 19 & 8.0 \\
\hline Chest & 20 & 8.4 \\
\hline Neurology & 15 & 6.3 \\
\hline Dermatology & 15 & 6.3 \\
\hline $\begin{array}{ll}\text { Cardio } & \text { vascular } \\
\text { disease } & \end{array}$ & 10 & 4.2 \\
\hline \multicolumn{3}{|l|}{ Years of experience: } \\
\hline - $<5$ & 50 & 21.1 \\
\hline - $5-<10$ & 66 & 27.8 \\
\hline - $10-<15$ & 39 & 16.5 \\
\hline - $15-<20$ & 39 & 16.5 \\
\hline - 20 and more & 43 & 18.1 \\
\hline Mean \pm SD & \multicolumn{2}{|c|}{$11.1 \pm 7.1$} \\
\hline
\end{tabular}




\section{Results:}

Table (2): Factors promote empowerment as reported by studied nurses according to departments, (n=237).

\begin{tabular}{|c|c|c|c|c|c|}
\hline \multirow{2}{*}{ Factors promote empowerment } & \multicolumn{4}{|l|}{ Department } & \multirow{2}{*}{ ANOVA } \\
\hline & $\begin{array}{l}\text { General } \\
\text { surgical }\end{array}$ & $\begin{array}{l}\text { Special } \\
\text { surgical } \\
\end{array}$ & $\begin{array}{l}\text { General } \\
\text { medical }\end{array}$ & $\begin{array}{l}\text { Special } \\
\text { medical }\end{array}$ & \\
\hline \multicolumn{6}{|l|}{ I- Empowerment Meaning } \\
\hline Mean \pm SD & $12.56 \pm 1.81$ & $12.39 \pm 2.36$ & $12.98 \pm 1.67$ & $12.43 \pm 2.97$ & \multirow{2}{*}{0.531} \\
\hline Range & $8-15$ & $6-15$ & $6-15$ & $3-15$ & \\
\hline \multicolumn{6}{|l|}{ II-Empowerment Competence } \\
\hline Mean \pm SD & $13.10 \pm 2.08$ & $11.76 \pm 2.82$ & $13.21 \pm 1.38$ & $12.88 \pm 2.36$ & \multirow{2}{*}{$0.009 *$} \\
\hline Range & $6-15$ & $5-15$ & $10-15$ & $3-15$ & \\
\hline \multicolumn{6}{|l|}{$\begin{array}{l}\text { III- Empowerment Self } \\
\text { Determination }\end{array}$} \\
\hline Mean \pm SD & $11.15 \pm 2.40$ & $9.89 \pm 2.68$ & $11.83 \pm 1.69$ & $11.13 \pm 3.08$ & \multirow{2}{*}{$0.006 *$} \\
\hline Range & $3-15$ & $3-15$ & $8-15$ & $3-15$ & \\
\hline \multicolumn{6}{|l|}{ VI-Empowerment Impact } \\
\hline Mean \pm SD & $10.43 \pm 2.79$ & $9.39 \pm 2.85$ & $10.47 \pm 2.63$ & $10.82 \pm 3.57$ & \multirow{2}{*}{0.132} \\
\hline Range & $4-15$ & $3-14$ & $3-15$ & $3-15$ & \\
\hline \multicolumn{6}{|l|}{ V-Procedural Justice } \\
\hline Mean \pm SD & $17.92 \pm 5.48$ & $17.84 \pm 5.46$ & $19.85 \pm 4.86$ & $\mathbf{1 9 . 8 7} \pm 5.79$ & \multirow{2}{*}{0.057} \\
\hline Range & $9-30$ & $6-28$ & $10-30$ & $6-29$ & \\
\hline \multicolumn{6}{|l|}{ IV-Interactional justice } \\
\hline Mean \pm SD & $25.03 \pm 10.26$ & $25.44 \pm 9.24$ & $29.38 \pm 8.66$ & $28.65 \pm 9.63$ & \multirow{2}{*}{$0.027 *$} \\
\hline Range & $9-45$ & $9-41$ & $9-44$ & $9-43$ & \\
\hline
\end{tabular}

(*) Statistically significant at P-value $\leq 0.05$ 
Table (3): Factors promote empowerment as reported by studied nurses according to sex, $(\mathbf{n}=\mathbf{2 3 7})$.

\begin{tabular}{|c|c|c|c|}
\hline \multirow{2}{*}{ Factors promote empowerment } & \multicolumn{2}{|l|}{ Sex } & \multirow{2}{*}{ t- test } \\
\hline & $\begin{array}{l}\text { Male } \\
(n=65)\end{array}$ & $\begin{array}{l}\text { Female } \\
(n=172)\end{array}$ & \\
\hline \multicolumn{4}{|l|}{ I- Empowerment Meaning } \\
\hline Mean \pm SD & $12.98 \pm 1.61$ & $12.44 \pm 2.52$ & \multirow{2}{*}{0.108} \\
\hline Range & $7-15$ & $3-15$ & \\
\hline \multicolumn{4}{|l|}{ II- Empowerment Competence } \\
\hline Mean \pm SD & $12.98 \pm 2.10$ & $12.79 \pm 2.27$ & \multirow{2}{*}{0.551} \\
\hline Range & $5-15$ & $3-15$ & \\
\hline \multicolumn{4}{|c|}{ III- Empowerment Self-Determination } \\
\hline Mean \pm SD & $10.98 \pm 2.06$ & $11.15 \pm 2.80$ & \multirow{2}{*}{0.664} \\
\hline Range & $3-15$ & $3-15$ & \\
\hline \multicolumn{4}{|l|}{ IV- Empowerment Impact } \\
\hline Mean \pm SD & $10.92 \pm 2.32$ & $10.20 \pm 3.29$ & \multirow{2}{*}{0.111} \\
\hline Range & $4-15$ & $3-15$ & \\
\hline \multicolumn{4}{|l|}{ V-Procedural Justice } \\
\hline Mean \pm SD & $19.29 \pm 4.92$ & $18.90 \pm 5.72$ & \multirow{2}{*}{0.627} \\
\hline Range & $9-30$ & $6-30$ & \\
\hline \multicolumn{4}{|l|}{ VI- Interactional justice } \\
\hline Mean \pm SD & $27.09 \pm 9.11$ & $27.40 \pm 9.89$ & \multirow{2}{*}{0.827} \\
\hline Range & $9-42$ & $9-45$ & \\
\hline
\end{tabular}

(*) Statistically significant at P-value $\leq \mathbf{0 . 0 5}$ 
Table (4): Factors promote empowerment as reported by studied nurses according to years of experience, $(\mathbf{n}=\mathbf{2 3 7})$.

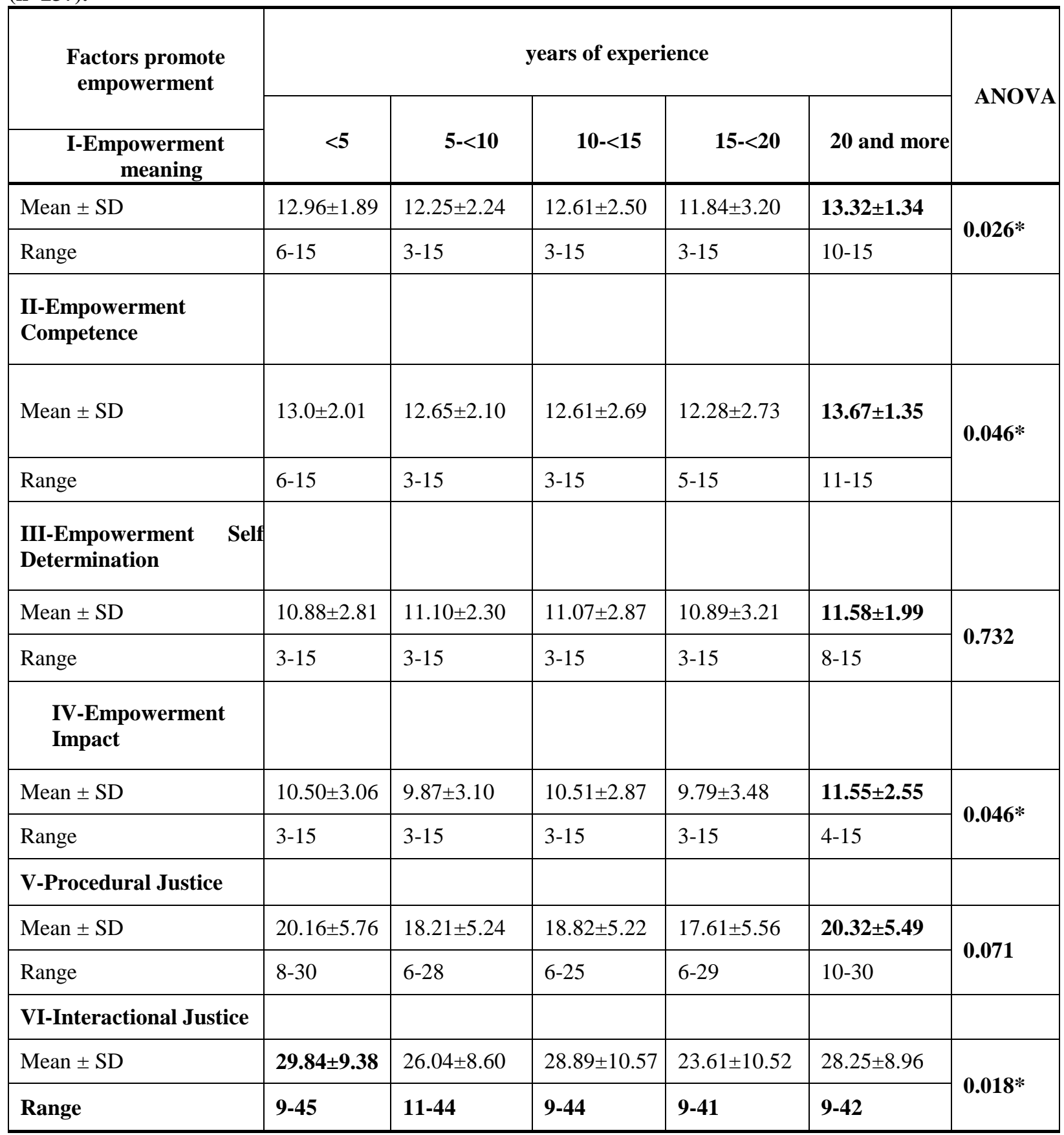

(*) Statistically significant at P-value $\leq \mathbf{0 . 0 5}$ 
Table (5): Suggestions by studied nurses for improving work empowerment at Main Assiut University Hospital, $(\mathbf{n = 2 3 7 )}$.

\begin{tabular}{|l|l|l|}
\hline Suggestions & No. & $\mathbf{\%}$ \\
\hline 1. Providing adequate medical instruments which need to do work. & 118 & $\mathbf{4 9 . 8}$ \\
\hline 2. Increase financial incentives & 106 & $\mathbf{4 4 . 7}$ \\
\hline $\begin{array}{l}\text { 3. Finding a distinguish , co-operated and fairness management } \\
\text { from nursing service administration personnel. }\end{array}$ & 62 & 26.2 \\
\hline 4. Increasing salaries for nursing personnel (staff). & 130 & $\mathbf{5 4 . 9}$ \\
\hline 5. Increasing fringe benefits for evening and night shifts. & 89 & 37.6 \\
\hline 6. Good treatment and respect from bosses. & 82 & 34.6 \\
\hline 7. Head nurse must hold a meeting periodically to explain work plan. & 74 & 31.2 \\
\hline 8. Let nurses share in decision making related to the work. & 59 & 24.9 \\
\hline 9. Giving concern to nurses rights and advocate for them. & 106 & $\mathbf{4 4 . 7}$ \\
\hline
\end{tabular}

Table (1): Shows that one third (33.3 \%) of nurses are working in special medical departments; the majority of them were females (72.6\%). Regarding educational level $\mathbf{( 9 6 . 6 \% )}$ have diploma degree, $(\mathbf{5 6 . 5} \%)$ of them aged less than 30 years and (27.8\%) have years of experience from 5-<10 years.

Table(2):Illustrates that the highest mean scores were in general medical department as regard to empowerment meaning, empowerment competence, empowerment self determination and interactional justice $\quad(12.98 \pm 1.67 ; \quad 13.21 \pm 1.38 ; \quad 11.83 \pm 1.69$; 29.38 \pm 8.66) respectively. In addition, the highest mean scores were in special medical department as regard to empowerment impact and procedural justice $(\mathbf{1 0 . 8 2} \pm \mathbf{3 . 5 7} ; \mathbf{1 9 . 8 7 \pm 5 . 7 9 )}$ respectively. There were statistically significant differences among empowerment competence, empowerment self determination and interactional justice with department $(0.009 ; 0.006$ and 0.027$)$ respectively. While, there was no statistically significant differences between empowerment meaning, empowerment impact and procedural justice with department.

Table (3): Displays that the highest mean scores were in male with regard to empowerment meaning, empowerment competence, empowerment impact and procedural justice $(\mathbf{1 2 . 9 8} \pm \mathbf{1 . 6 1} ; \mathbf{1 2 . 9 8} \pm \mathbf{2 . 1 0}$ ;10.92 $\pm 2.32 ; 19.29 \pm 4.92)$ respectively .In addition, the highest mean scores were in female as regard to empowerment self determination and interactional justice $(\mathbf{1 1 . 1 5} \pm \mathbf{2 . 8 0} ; \mathbf{2 7 . 4 0} \pm 9.89)$ respectively. While there were no statistically significant differences between sex and all factors of empowerment among the studied nurses.

Table (4): Depicted that the highest mean scores were among nurses with experience 20 years and more with regard to empowerment meaning, empowerment competence, empowerment self determination, empowerment impact and procedural justice $\quad(13.32 \pm 1.34 ; \quad 13.67 \pm 1.35 ; \quad 11.58 \pm 1.99$; $11.55 \pm 2.55 ; 20.32 \pm 5.49$ ) respectively. In addition, the highest mean scores were among nurses with experience less than $\mathbf{5}$ years with regard to interactional justice $\mathbf{( 2 9 . 8 4} \pm \mathbf{9 . 3 8})$. There were statistically significant differences between empowerment meaning, empowerment competence, empowerment impact and interactional justice with years of experience $(0.026 ; 0.046 ; 0.046$ and 0.018$)$ respectively .While there were no statistically significant differences between empowerment self determination, procedural justice with years of experience.

Table (5): Shows that suggestions of nurses about how to improve their work empowerment, more than half of staff nurses suggest increasing salaries of nursing, about half of staff nurses suggest providing adequate medical instruments which need to do work, 
less than half of staff nurses suggest increasing financial incentives and giving concern to nurses rights and advocate for them. Also more than one third of staff nurses suggest increasing fringe benefits for evening and night shifts, good treatment and respect from bosses ,and one third of staff nurses suggest head nurse must hold a fixed meeting periodically to explain work plan $\mathbf{( 5 4 . 9 \% , 4 9 . 8 \% , 4 4 . 7 \% , 3 7 . 6 \% , 3 4 . 6 \%}$, and $31.2 \%)$ respectively. While the lowest percentage was regarded to let nurses share in decision making related to the work $(\mathbf{2 4 . 9} \%)$.

\section{Discussion:}

In many large organizations, the workforce often feels frustrated and stifled by not being permitted to have any input into their work. This situation leads to unnecessary stress and lack of productivity. Staff members are invited to be a part of their own operations: They are encouraged not only to identify and "own" the problem but also, in turn, to "own" its solution so that a positive working environment can be created and maintained (Cynthia, 2003). It is well known that nurses are more effective if they are involved in making decisions about their own practices. Nurses report better job satisfaction if their voices are heard (Kristin , 2008).

Staff empowerment enables employees to make independent autonomous decisions in almost any situation. This empowerment would necessitate guidelines for the conduct of whatever role staff members occupy. Managers create a nurturing environment in which staff can learn, grow, improve, and function effectively. Staff empowerment gives employees a sense of trust, importance and capability, thus creating a positive work environment (Cynthia, 2003).

The present study confirmed that, regarding departments, one third of nurses are working in special medical units, the majority of them are females, having diploma degree, and more than half of them aged less than 30 years (Table, 1). These results might be attributed to the need of more years of experience to feel empowered in the work.

The study findings revealed that there was relation between empowerment factors and department and with the highest mean score present in general medical department and there was a highly statistically significant difference between empowerment factors and department (Table, 2). This might be attributed to that leader who works in general medical department affect on employee and he provided them with power, information and shared them in decision making for that employee feel empowered. This finding was consistent with Huang, (2005) who mentioned that perception of the empowerment that the Nurse Administration Chief pay attention to the management of the nurses' empowerment, as well as improve the perception of the nurses' empowerment. The Administration Chief also build up the environment to promote the nurses to show their nursing professional potential it, and to develop the nursing characters and functions, and thus to improve nurses' job satisfaction.

The study findings demonstrated that the highest mean scores of empowerment factors (empowerment meaning, and empowerment competence)are found among male of the study nurses, while the highest mean scores of empowerment factors (empowerment self determination, empowerment impact, procedural justice and interactional justice ) are found among female of study sample, with no statistically significant differences between sex and empowerment meaning, empowerment competence , empowerment self determination, empowerment impact, procedural justice and interactional justice. This might be explained by both females and males are similar in perception of empowerment and they have the same degree of feeling of empowerment and the organization provided them with power (Table, 3). These findings were inconsistent with Zoe, (2001) who mentioned that, men hold more power in organizations than women is widely accepted. Thus male employees feeling more empowered than female employees.

On the other hand, the study findings were consistent with Rangriz, (2011) who asserted that, there is no obvious difference between the average responses of men and women in terms of obtained averages with regard to employees' gender and psychological empowerment. However, it can be said that women have higher degree of the feeling of psychological empowerment. As a matter of fact, the feeling of psychological empowerment among women is higher than men with a slight difference.

The study findings revealed that the highest mean scores found among nurses who are having nursing experience more than ten years and there was a highly statistically significant difference between experience and empowerment factors (Table, 4). This might be attributed to when employees have information; knowledge and experience become more empowered than others. This finding was consistent with Zoe, (2001) who clarified that work experience, interpersonal sources of power in organizations comprised reward power; coercive power; legitimate 
power; expert power; and referent power, therefore, present relationships between total work experience and all dimensions of subjective empowerment. In addition, these findings were consistent with Suominens, (2008) who mentioned that nurses with more than 20 years of work experience felt stronger behavioral empowerment in comparison with those less than 20 years of work experience.

The study findings showed that nurses suggestions, more than half of studied nurses suggested increasing salaries for nursing (54.9\%) ,about half of staff nurses suggested for providing adequate medical instruments which need to do work $\mathbf{( 4 9 . 8 \% ) , ~ l e s s ~ t h a n ~ h a l f ~ o f ~ s t a f f ~ n u r s e s ~ s u g g e s t e d ~}$ increase financial incentives and giving concern to

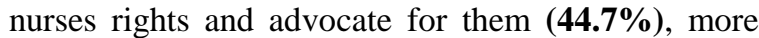
than one third of staff nurses suggested for increasing fringe benefits for evening and night shift (37.6\%), good treatment and respect from bosses $\mathbf{( 3 4 . 6 \% )}$ and suggested that head nurse should hold fixed meeting periodically to explain work strategies( $31.2 \%)$ (Table, 5). This might be attributed to those nurses in the organization need to feel empowerment that will get through concern of their right, advocate them and respect from other this lead to increase sense of empowerment and organizational commitment. These findings were consistent with Chandler, (2007) who clarified that staff nurses empowerment has an impact on their perceptions of fair management practices, feelings of being respected in their work settings, and their trust in management, which ultimately influence their job satisfaction and organizational commitment.

\section{Conclusions:}

- There was a highly statistically significant difference between empowerment factors and department especially in general medical department

- Highest mean scores of empowerment factors (empowerment meaning, and empowerment competence) found among male, while the highest mean scores of empowerment factors (empowerment self determination, empowerment impact, procedural justice and interactional justice) found among female.

- There were no statistically significant differences between sex and all factors of empowerment among the study nurses.

- Highest mean scores found among study sample who having nursing experience more than ten years and there was a highly statistically significant differences between years of experience and all empowerment factors.

\section{Recommendations: \\ A-Empowerment should be introduced gradually in order to be fully integrated into the working environment through:-}

1-Nurse managers must provide staff nurses by sources of job-related empowerment, namely access to opportunities, information, support and resources.

2-Nurses should be allowed to participate in decision making to empower them, as well as increasing their feeling of autonomy.

B- Actions that may facilitate movement toward more organized atmosphere and establish better staff's psychological empowerment include:

1- Using activities such as applying tools for facilitating organizational communications, creating flexibility in organization's practices, reducing formalization, assigning the enforcement of laws to the employees, investing individuals with authority to control activities within their work scope and decentralizing in organizational structure, their participation in decisions and organizational planning.

2-Maintaining justice in organizational relations, maintaining the material motivations level, all in all can be some of the consolidating and facilitating dimensions of execution of psychological empowerment.

3- Managers must think of releasing employees' competencies which will create more commitment and ownership of their jobs at work. This encourages managers to minimize their efforts in direction, supervision, and follow up through empowering those with skill, knowledge and information at their fingertips.

\section{References:}

1. Chandler, G. (2007): Power and Empowerment in Nursing: Looking Backward to Inform the Future: Historical Review of Nurses' Power over Nursing Practice OJIN: The Online Journal of Issues in Nursing. 2007; Vol.22, No. 8, (C) 2007 American Nurses Association, P.6.

2. Cynyhia, K. (2003): Work empowerment as an antecedent to organizational commitment in the Hong Kong quantity surveying profession. Surveying and Built Environment, Vol.17, No.2, Pp.63-67.

3. Hassan, F. (2010): "Work Empowerment as Perceived by Nurses and Physicians Working at National Heart Institute" Faculty of Nursing; Ain Shams University Pp.3-5.

4. Huang, S. (2005): The Relationships between the Perception of Empowerment and its Related 
Factors in the Nurses, Tzu Chi Nursing Journal, Vol. 5, No.5, Pp.93-104.

5. Kotelnikov, V. (2001): Employee Empowerment Harvesting the Creative and Emotional Power of All Your People Ten3 Business e-Coach, performance management article.

6. Kristine, P. (2008): Power to stand: Promoting nursing empowerment in health care, ANCC Website - The American Nurses Credentialing Center Nursing Diary, Professional Nurse Educators Group Blog, P.354.

7. Kukkanen, L. (2003): Factors Promoting or Impeding empowerment, JONA, Vol.33, No.4, Pp.211-215.

8. Leiter, M. \& Laschinger, H. (2006): Relationships of work and practice environment to professional burnout. Nursing Research, Vol.55, No.2, Pp .137-146.

9. Mondy,N. (2002): Employee empowerment: An integrative psychological approach. Applied Psychology: An International Review, Vol. 50, No. 1, P.153.

10. Nikkhah, H. (2010): The Effect of Women's Socio-demographic Variables on their Empowerment, Journal of American Science 2010, Vol. 6 ,No. 11, P.431.

11. Rangriz,H. (2011): The relationship between organizational Structure and employees' empowerment in National iranian oil products distribution Company, Kuwait Chapter of Arabian Journal of Business and Management Review Vol. 1, No.1; September 2011,Pp.56-65.

12. Setoyama, M. (2000): Taking empowerment to the next level: A multiple-level model of empowerment, performance, and satisfaction. Academy of Management Journal, Vol.47, No.5, Pp.332-349.

13. Shelton, S. (2002): Employees, Supervisors, and Empowerment in the public sector: The Role of Employee Trust, Unpublished, Doctoral degree thesis, Graduate Faculty of North Carolina State University, Pp.30-35.

14. Suominens.T. (2008): Work empowerment as experienced by nurses in elderly care Inc. All rights reserved. Journal of Professional Nursing, Vol. 24, No 1, Pp. 42-45.

15. Watson, S. (2003): Significant conditions in Employees Empowerment: the Case of Jordanian four Star hotels bring out the best in employees through empowerment, P.345.

16. Yi Liu, B. (2008): Taiwanese Nurses' Empowerment and Participation in Decision Making, Doctoral Degree, Faculty of the Graduate School, the University of Texas at Austin, Vol.30, No. 49, P.413.
17. Zoe, S. (2001): Individual, Job, Organizational and Contextual Correlates of Employment Empowerment: Some Greek Evidence, Electronic Journal of Business Ethics and Organization Studies, Vol. 9, No. 2, Pp.36-38. 